\title{
The Impact of Physical Support and Contact Personnel on Patient Satisfaction at dr. Soebandi Regional Hospital of Jember
}

\author{
Moh. Wildan \\ Health Polytechnic of Malang, Republic of Indonesia
}

\begin{abstract}
The low level of patient satisfaction toward the hospital's treatment becomes todays Indonesian hospitals problem. The Physical supports such as dirty, cramped, messy treatment rooms, limited parking space, and other restricted means of supports (ATM, Shop, Canteen, etc.) commonly found at the hospital do not satisy the patient. In addition many of the hospital officers as the contact personnels perform under standard like being less firendly, unneat performance, complicating entrance procedures, and commonly being unpunctual. This study aims to examine and analyze the effect of physical support and contact personnel on patient satisfaction in hospitals. This research was explanatory using ex post facto method and the associative explanatory level from causal variables and quantitative data. The purposive sampling technique was applied to get 50 samples and the data were analyized through multiple linear regression equation. The results of regression test analysis showed value of significance ( $\rho$ ) physical supports variable equals to 0,017 and contact personnel variable equals to 0,008, while the Anova for physical support variable and personnel contact significance value equals to 0.000 , it can be concluded that: (1) Physical support partially brings up positive and significant impact on patient satisfaction. (2) Contact personnel partially brings up positive and significant impact on patient satisfaction. (3) Physical support and contact personnel simultaneously brings up positive and significant impact on patient satisfaction. This findings imply that the improvement of physical support and contact personnel at the hospital will raise up patient satisfaction, so the improvement of the physical support of the hospitals and the employee contact personnel will be able to raise up the positive image and patient satisfaction.
\end{abstract}

Keywords: Physical Support, Contact Personnel, Patient Satisfaction

\section{Introduction}

The public hospital as a health care facility in Indonesia holds an important role in health development. The main mission is to provide qualified and affordable health services for the community to improve community health while the specific mission is determined by the aspirations of its owner. Public hospitalis hospital providing health care of all kinds of diseases from basic to specialictic diseases. The key tasks of public hospitals are take effort of health efficiently and effectively by prioritizing the effort to cure (curative) and recover (rehabilitative) carried out in harmony and integrated with the efforts to increase (promotion) and prevent (preventive) and carry out the referral (Surjaningrat, 1997). In order to formulate the order of public hospital services, improvement and development of health services and functions of public hospitals, the Ministry of Health of Indonesia determines Hospital Service Standards containing important criteria regarding the type of service discipline which deals mainly with the structure and process of care. In addition, the increase in health care is not solely determined by the availability of fine physical facilities, but more is on the courtesy and the quality of professionalism of the personnel serving the patients.

Based on the findings by Hardiman (2003), the health care system in Indonesia has yet been good. The hospital has not been able to guarantee the quality of health services, such as the unpunctual doctors, the length of the waiting time to get services, the uncomfortable waiting room, no continuity of service, no guarantee of the exact delivery time of the drug, and off line prescription system. Many hospitals are not yet consumer oriented and even they do not provide ease of access to serve the patients. Additionally, Sulastomo (2000: 145) states the hospital hall ways and the waiting rooms are still far from being clean and order. The state of being "huddles" and "chaotic" are easily seen in Indonesian hospitals, and it even becomes worse as hospitals usually do not provide enough parking space. These facts dropped the hospital image in Indonesia compared to abroad. The public hospital as a health services industry, in one hand,has to survive and on the other hand has to undergo its social function to provide the community with general hospital services. Moreover, consumers desiring a versatile instant and wanting excellent service urge the management of public hospitals to think extra hard and avoid errors in providing its service. The public hospitals should provide services in accordance with the wishes of the customer, or other wise customers will switch to other better hospitals which can satisfy their wishes. Doctor services as medical and paramedical personnel are in this case inclusively bounded with health services at the hospital. 
The problems above indicate that the service delivery system including physical support and contact personnel at hospitals in Indonesia tend to be not yet in a good standard. Physical support consists of a wide range of physical facilities and complementary components of service offered at the hospital, while the contact personnel are medic, paramedic and non-medicinvolved in the service delivery and have direct contact with patients and their families. In achieving the goal oriented to patient satisfaction as well as aspects of hospital facilities, the role of doctor, paramedic and non medic is of necessary because their performance will determine the perception and the perceived performance of patients with the services provided. Service delivery system including physical support and contact personnel will affect the image of the hospital. In the world of marketing, the establishment of a positive corporate image will help the company in its marketing activity, because in conditions of tight competition each company will seek to place itself as much as possible in the eyes of consumers in order to be trusted to meet their needs.

According Muninjaya (2004: 231) hospital utilization by society is measured from the contact rate, hospitalization rate, outpatient rate and emergency outpatient rate. Contact rate is the ratio of total patient out alive and die by the population and multiplied by $100 \%$. Hospitalization rate is the ratio of total days of treatment by total population and multiplied by $100 \%$. Out patient visit rate is the ratio of total new and old by total population and multiplied by $100 \%$. Emergency out patient rate is the ratio of total outpatient by total population and multiplied by $100 \%$. Many factors affect the rate of utilization of health care facilities including hospitals such as the degree of public health (which can be seen from the mortality and morbidity), socio economic (income per capita, education, a clean and healthy life behavior), the environment and public confidence. People trust is closely related to patient satisfaction. According to Kotler (2003: 326) customer satisfaction is the public perception abut the company or its products. Patient satisfaction in hospitals is the overall evaluation about the hospital in the eyes of customers and is measured using three indicators, namely, 1) overall opinion about the hospital, 2) opinion on the contribution of the hospital to the community, and 3) preference for the hospital. Confidence (trust) emerges if a party entrusts on the integrity and reliability of others (Morgan and Hunt, 1994: 23).

The public hospital must continually improve customer satisfaction and trust. Satisfaction and confidence of customers affected by service delivery system include physical support and contact personnel. Improvement efforts are required to conduct continual improvements to both service components, the back office and the front office, so that customers are increasingly interested in using health care services in the public hospitals. The system of service delivery will provide stimuli to the public to use the services of the hospital, because the hospital is expected to be able to design a system of service delivery that is unique, different from other hospitals, so as to give a different impression with its competitors, satisfaction, and trust from public as users of health services. According to Cooper (1994: 106) users of health care services including hospitals always pay attention to the quality of the medical staff, emergency care, care nurses, the availability of a complete service, the doctor's recommendation, the modern equipment, polite employees, a good environment, previous hospitalized experience, the maintenance costs, family recommendation, hospitlal distance to home, private rooms, and a friend's recommendation. Contact elements (physical environment and contact personnel) influence on patient satisfaction (Nguyen and Leblanc, 2002: 246), while Kotler (2003: 63) expressesthat satisfaction and image can be formed through symbols, colors, slogans, special attributes, building or physical space and ambience. The relationship between patient satisfaction and customer loyalty is reflected in the intention of repurchasing and desire to recommend to others. Belanger et al (2002: 687) states that the image affects satisfaction, then satisfaction affectstrust, and trust affects customer commitment. Customer commitment has a strong influence on purchase intentions, the price intensity and word of mouth (WOM)

The effort to implement the service delivery system to the tangible customer service program is in form of supporting physical facilities (immovable tangible objects perceiveable to the patient) such as; adequate buildings, representative equipment, the beautiful building interior and exterior, parking spaces, canteen, bank, security, total employee support, and good management of public hospitals for the purpose of increased capabilityof the hospital. The importance to the effort is due to hospital services which is customer servicefocus in which the activities are oriented to people (people based service). The hospital physical environment includes location, equipment, and facilities critically considered by hospital patients (Hutton and Richardson, 1995: 52), while the contact personnels are all human elements involved in the delivery of services and further affect the perception of the customers. According to Nguyen and Leblanc (2002: 245) contact personnel composed of all employees at the front lines of the organization and have direct contact with customers. The preliminary survey conducted at dr. Soebandi Regional Hospital of Jember in January 2015 showed that of the 20 patient respondents seeking treatment at outpatient unit and inpatient unit, 50\% felt not satisfied, $20 \%$ fairly satisfied and $30 \%$ dissatisfied. Of the $50 \%$ not satisfied respondents argued the causesof discontent were (1) the long queue, (2) very limited space, (3) less punctual physicians and paramedics, (4) long wait of laboratory results and (5) less comunicative physicians and paramedics and hasty observations. 
Based on the findings of the preliminary study and to obtain empirical evidence,the study on the influence of services (physical support and contact personnel) to the patient satisfaction at dr. Soebandi Regional Hospital of Jember was then necessary.

\section{Purposes of the Study:}

1) Analyze the effects of physical support to patient satisfaction in hospital.

2) Analyze the effects of contact personnel to satisfaction of patients in hospital.

3) Examine and analyze the effect of physical support and contact personnel simultaneously on patient satisfaction in hospital

\section{Design}

\section{Research Methods}

This study was an explanatory research or confirmatory research because the aim was to explain the causal relationship among variables through hypothesis testing (Singarimbun and Effendi, 1995: 3-4). Information or data on physical support, contact personnel, and patient satisfaction were obtained from hospital patients. To answer the whole problems, as revealed in the identification and formulation of the problem in this study, the logical framework was developed in order to formulate the problems mentioned by using a schematic approach as shown below:

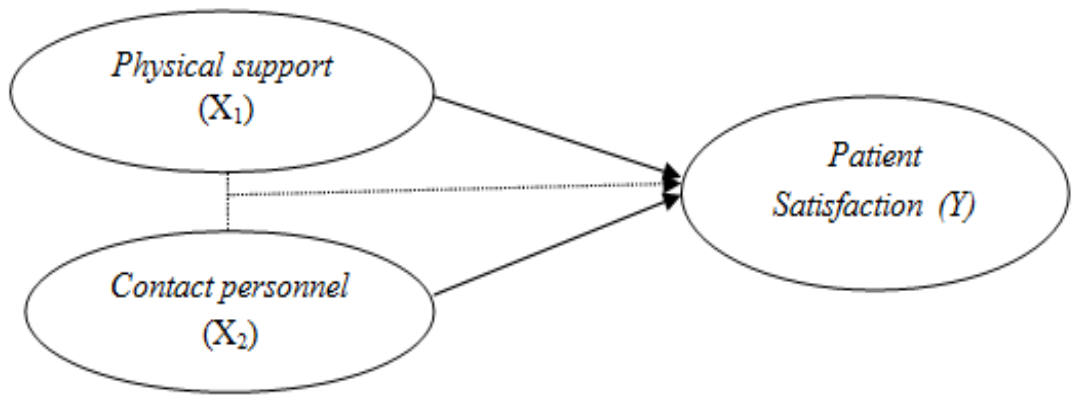

Figure 1: Conceptual Framework

\section{Research Population}

The population of the study was patients at the dr. Soebandi Regional Hospital of Jember. The sample participants were inpatients using the services of the hospitalwith at least 3 days of treatment.

Samples and Sampling Techniques

The sampling technique used was stratified sampling technique determined by the classes based. At the hospital the class types are categorized from care services into class 1, class 2 and class 3. Sampling techniques were determined by purposive sampling using $20 \%$ of the population (Sugiono, 2000: 52). As for counting the number of patients in the sample can be seen in the following table:

Table 1: The number of sample based on care service classes at the dr. Soebandi Regional Hospital of Jember

\begin{tabular}{|l|l|l|l|}
\hline No & Care Service Class & $\begin{array}{l}\text { Number of Patient / month } \\
\text { (Population) }\end{array}$ & Sampel \\
\hline 1 & I & 102 & 10 \\
\hline 2 & II & 148 & 15 \\
\hline 3 & III & 250 & 25 \\
\hline & Total & 500 & 50 \\
\hline
\end{tabular}

The criteria used as the sample respondents were:

1) Inpatients with at least 3 days of treatment.

2) Patients with unimpaired consciousness and could communicate.

3) Parents of pediatric patients.

4) Patients or families willing to become respondents

\section{Research Variables}

1) Independent variable consisted of: physical support as the first independent variable (X1); contact personnel as the second independent variable (X2).

2) Dependent variable was the Patient Satisfaction (Y) 


\section{Operational Definition of Variables}

1) Physical Support (X1): related to physical facilities and complementary components of offered services.

The indicators used were:
a) building facilities available
b) availability of equipments
c) ambience of the hospital
d) hygiene of the hospital
e) primeness of the location
f) the food menu provided

2) Contact Personnel (X2): All human elements involved in the delivery services and have direct contact with customers. The indicators used were:

a) medic, paramedic and non-medic appearance at the time of serving

b) the ability of medic, paramedic and non-medicat the time of serving

c) the way medic, paramedic and non medic serve the customers

d) the hospitality of the medic, paramedic and non medic at the time of serving

e) Responsiveness of the medical, paramedical and non medical personnel to customer complaints

f) the speed of medical, paramedical and non-medical personnel at the time of serving

3) Patient satisfaction (Y), the state in which the wishes, expectations and needs of patients were met. Patient satisfaction was a subjective value to the quality of services provided. The indicators used were;
a) the relationship of health personnel with patient
b) comfortable services
c) freedom of selection
d) effectiveness of service
e) affordability of service
f) aontinuity of service
g) security measures

The score range of each itemof above variables used Likert scale: $3=$ very satisfied; $2=$ sometimes; $1=$ not satisfied.

\section{Research Hypothesis}

Based on the framework, the research hypothesis formulated were as follows:

1. There is a significant influence of Physical support to client satisfaction at dr. Soebandi Regional Hospital of Jember.

2. There is significant influence on patients' satisfaction Contact Personnel at dr. Soebandi Regional Hospital of Jember

3. There is significant influence Physical Support and Contact Personnel jointly to client satisfaction at the dr. Soebandi Regional HospitalJember

\section{Results}

\section{Results and Discussion}

Table 2: Characteristics of Physical Support, Contact Personnel and Patient Satisfaction according to Patients Conducting Treatment at dr. Soebandi Regional Hospital of Jember

\begin{tabular}{|l|l|l|}
\hline \multicolumn{1}{|c|}{ Physical Support } & Frequency & Percentage \\
\hline Very Good & 6 & 12 \\
\hline Good & 10 & 20 \\
\hline Moderate & 20 & 40 \\
\hline Poor & 10 & 20 \\
\hline Very Poor & 4 & 8 \\
\hline Total Contact Personnel & 50 & 100 \\
\hline \multicolumn{1}{|c|}{ Patient Satisfaction } & 4 & \\
\hline Very Good & 10 & 8 \\
\hline Good & 27 & 20 \\
\hline Moderate & 5 & 54 \\
\hline Poor & 4 & 10 \\
\hline Very Poor & 50 & 8 \\
\hline Total & 14 & 100 \\
\hline & 30 & \\
\hline Very Satisfied & 6 & 60 \\
\hline Quite Satisfied & 50 & 12 \\
\hline Not Satisfied & & 100 \\
\hline Total & & \\
\hline
\end{tabular}


From the table 2; the majority of the respondents rated physical suport at dr Soebandi Regional Hospital of Jember moderate about $(40 \%)$, but still a few of them considered the Physical Suport very poor $(8 \%)$. For contact personnel the majority of the respondents rated moderate $(54 \%)$ but a few rated very poor $(8 \%)$. In terms of patient satisfaction the repsondents felt Quite Satisfied (60\%) although about (12\%) of them felt not satisfied.

Table 3: Regression Analysis between Independent Variables Physical Support (X1), Contact Personnel (X2) and Dependent Variable Patient Satisfaction (Y)

\begin{tabular}{|c|c|c|c|c|c|}
\hline Independent Variables & $\begin{array}{l}\text { Regression } \\
\text { Coefficient }\end{array}$ & $\begin{array}{l}\text { Error } \\
\text { Standard }\end{array}$ & t-ratio & Sig t & $\mathbf{r}^{2}$ Partial \\
\hline (Constant) & 17,765 & 2,284 & 7,778 & 0,000 & \\
\hline Physical Support $\left(\mathrm{X}_{1}\right)$ & 0,151 & 0,184 & ,818 & 0,017 & 0,118 \\
\hline Contact Personnel $\left(\mathrm{X}_{2}\right)$ & 0,301 & 0,167 & 1,802 & 0,008 & 0,254 \\
\hline \multicolumn{6}{|l|}{ Anova } \\
\hline Multiple R & \multicolumn{2}{|c|}{0,516} & & & \\
\hline R Squared & \multicolumn{2}{|c|}{0,266} & & & \\
\hline Adjusted R Squared & \multicolumn{2}{|c|}{0,235} & & & \\
\hline F Ratio & \multicolumn{2}{|c|}{8,519} & & & \\
\hline Sig F & \multicolumn{2}{|c|}{0,001} & & & \\
\hline D-W Test & \multicolumn{2}{|c|}{1,353} & & & \\
\hline
\end{tabular}

From the table 3; using the Anova the $\mathrm{F}$ value ratio equals to 8.519 with a significance level of 0.001.The regression model can be used to predict patient satisfaction. In other words, the physical support and contact personnel are equally influential on patient satisfaction at dr. Soebandi Regional Hospital of Jember.

\section{Discussion}

The effect of physical support to the patient satisfaction at dr. Soebandi Regional Hospital of Jember.

In table 3, the regression coefficienttest shows the influence of coefficient regression for physical support to patient satisfaction equals to 0.151 and the probability value equals to 0.017 . The hypothesis is proven and physical support partially has a significant effect on patient satisfaction. It means that every time one item is added to physical support, it will result in an increase of patient satisfaction of about 0.151 . According to Nguyen and Leblanc (2003: 245) physical support in the form of the physical environment is measured by the ambient conditions, atmosphere, exterior and interior design, decoration, parking facilities, appearance and location of buildings and parks. Ambient conditions consisted of an assortment of elements such as color, lighting, temperature, noise, odors and music. The hospital facilities include the location of the physical environment, equipment and facilitieswhich are critically considered by patients (Hutton and Richardson, 1995: 52). The primeness of hospital's location is laid out well connected to public facilities and convenience to achieve it. This is in accordance with the opinion of Sabarguna (2004: 12) who states that the location is used to achieve the intended customer and require a relatively quick time. The physical facilities are permanent tangible objects perceivable to the patient, such as; a representative equipment, beautiful building interior-exterior, parking facilities, bank, and security guarantees. Hospital equipment is the equipment owned by the hospital directly related to the patient needs, while according to Hutton and Richardson (1995: 52) food provided can be part of the physical evidence at the hospitalas well. Facilities provided for the consumer are tangible manifestations of the importance of the overall services offered (Lamb et. Al, 2002: 483). The comfort level in the hospital also needs to be considered in addition to facilities and equipment. This is in line with the opinion of Sabarguna (2004: 12) that the hospital needs, in addition to adequate equipment, to maintain comforts. Further the findings by Joseph and Cindy (1999: 104) in the banking industry revealed that the comfort level affected the quality of service delivery systems. More over the layout of the rooms and service procedures given by officers become important elements in the delivery of services. Service delivery systems in the form of physical support are related spatial layout and working procedures. Thus the comfort in the form of physical support has significant impact on patient satisfaction in a hospital.

\section{The effect of contact personnel to the patient satisfaction at dr. Soebandi Regional Hospital of Jember}

In table 3, the influence of the regression coefficients of the contact personnel to client satisfaction equals to 0.301 and the probability value equals to 0.008 . The hypothesis is proven and contact personnel partially has a significant effect on patient satisfaction. It meansevery time one item is added to contact personnel, it will result in an increase of patient satisfaction of about 0.301 Contact personnel are all human elements involved in the delivery of services and have direct contact with patients. According to Nguyen and Leblanc (2002: 245) contact personnel consisted of all employees at the front lines of the organization and have direct contact with customers. According to Snook (1992: 65) medical staffs of the hospital are doctor, dentist, pediatrist, and health professionals taking care of patients. Lim et. al (2000: 290) found that the most important 
element in service at the hospital were doctors and nurses. Doctors and nurses play a critical role in creating a quality of service at a hospital, while Adikoesumo (1997: 234) found that doctors and nurses played a role in encouraging the patient's recovery especially their hospitality and special attention to patients.

As a high contact service, personnel at the hospital is central to the delivery of services. Lovelock and Wright (2002: 197) stated; "in high-contact services, service personnel are central to the service delivery". Furthermore Lovelock and Wright (2002: 324) stated; "in the eyes of their customers, sevice personnel may also be seen as an integral part of the service experience". Meanwhile, according to Nguyen and Leblanc (2002: 250) contact personnel is measured by three items, namely, appearance, competence, and professionalism. According to Nguyen and Leblanc (2002: 245) the appearance of personnel is a combination of clothing, hairstyles, makeup and hygiene. In terms of competency employee should be supported by their expertise and experience. Zeithaml and Bitner (2000: 19) also explains that all the attitudes and actions of employees, even how they dress and perform have some impacts on consumer perception or the success of real time services. From the customer side, the speed of access to services is an important of the services delivery system (Best, 2000: 230). This is supported by Aschner (1999: 453) statement that in the field of services, almost all service attributes are determined by customer votes on the speed and accuracy of officers in responding to their complaints.

Commitment of human resources can definitely generate high-good business. Gaunaris (2002: 6) supports such opinion that personnels also functions as a service provider within the service organization and therefore should realize that they are actually marketer. It means their behavior will affect the success of an organization in the long term. Hair (1998: 9) in addition said that the service delivery system especially contact personnel was very crucial. The customer assessment will be more about the speed and accuracy of the officers in response to their complaints. In conclusion comfort provided by contact personnel greatly influences patient satisfaction in a hospital.

\section{The effect of simultaneously physical support and contact personnel to the patient satisfaction at dr. Soebandi Regional Hospital of Jember.}

In table 3, the results of ANOVA test obtained F count equals to 8.519 with a probability value of 0.001, the hypothesis is proven and it means physical support and contact personnel simultaneously have a significant effect on inpatient satisfaction in dr. Soebandi Regional Hospital of Jember.These findings are in line with Lovelock and Wright (2002: 60) findings that the service business is seen as a system consisting of service operation system and service delivery system. The service operating system is an unseparable part of service businesssystemwhere input is processed and the product elements are created by the service components; human resources and physical components. The service delivery system isclosely related to when, where, and how services are delivered to customers including the elements of the system in service operations and other matters presented to other consumers.

As a system, service business including hospital services consists of service operation system and service delivery system as tangible service parts to the consumers (front office), such as; the interconnection between physical support and contact personnel and the indirect customer service part which consumers consider as a core technical activities (back office) as well as the intangible activities perceivable to consumers. Meanwhile, Hair (1998: 154) states that the system of service delivery is shaped through, (1) information system support, (2) the company location, (3) the atmosphere of the place of service/decor, (4) space design, (5) the customer handling management, (6) courtesy to customers, and (7) the equipment and company policies. Best (2000: 205) also explained that the operating system and service delivery were closely bounded to three things: (1) after-sales service, (2) the availability linked particularly to the access speed to such services, and (3) services time of transaction, such as the system of payment by credit, money back guarantee, and so forth.

According Stavins and Fache (2004: 421) using the integrity and reliability as an indicator to measure the trust of customers, it was found that the contact personnel and physical environment affected customer confidence, in addition, Bloemer et.al (2002: 68) states that corporate image affects customer satisfaction, satisfaction affects customer trust and trust affects customer commitment. Customer commitment has a strong influence on purchase intentions, the intensity of the price and word of mouth (WOM).

\section{Conclusions and Suggestion}

\section{Conclusion}

From the discussions the conclusion can be formulated as follows;

1. Physical support brings positive and significant impact on patient satisfaction. This finding implies that the improvement of physical support will bring up patient satisfaction. In other words the physical support owned by dr. Soebandi Regional Hospital Jember has been able to bring up patient satisfaction;

2. Contact personnel brings positive and significant impact on patient satisfaction. This finding implies that the improvement of contact personnel performed by employees dr. Soebandi Regional Hospital of Jember will 
bring up its patient satisfaction. In other words the employee contact personnel of dr. Soebandi Regional Hospital of Jember has been able to raise patient satisfaction;

3. Physical support and contact personnel simultaneously bring positive and significant impact on patient satisfaction. This finding implies that the improvement of both physical support and contact personnel collectively will increase patient satisfaction. In other words both the physical support owned by dr. Soebandi Regional Hospital of Jember and the employee contact personnel of dr. Soebandi Regional Hospital of Jember have been able to bring up a positive image and patient satisfaction.

\section{Suggestion}

Based on the conclusion of the study, the suggestions expected to be useful for practical interests and for further research are as follows;

1. There's a need to improve physical support to raise patient trust through easier access to hospital location, better patient care and comfort of the treatment room, provision of equipment according to the needs, increased cleanliness of service place and patient treatment rooms, and more variety of food menu suitable to the patient's needs;

2. There's a need to raise contact personnel by increasing the ability, responsiveness, speed in providing services, neat and attractive appearance as well as better courtesy of hospital employees like politeness, friendliness, and smile in serving all patients.

3. There's a need to to conduct further research on this topic with samples and a more representative method.

\section{References}

[1] Adikoesoemo, Suparto. 1997. Manajemen Rumah Sakit. Jakarta: Pustaka Sinar Harapan : 46-48.

[2] Aschner, Gabor S. 1999. Meeting Customers' Requirements and What Can be Ecpected. The TQM Magazine Vol.11 No. 6: 450455 .

[3] Belanger, Charles, Joan Mount and Mathew Wilson. 2002. Institutional Image and Retention. Tertiary Education and Managemenet 8: 217-230.

[4] Best, Rogers. 2000. Market Based Management. Strategies for Growing, Customer Value and Profitability. Upper Saddle River New Jersey: Prentice Hall: 205-230.

[5] Blomer, Seyhmus. 2002. Dimensions of Customer Loyalty-Separating Friends from Well Wishers Cornell Hotel and Restaurant. Administration Quarterly, Cornel University: 49-50.

[6] Cooper, Philip D. 1994. Health Care Marketing: A Foundation For Managed Quality. Gaithersburg, Maryland: Aspen Publisher, Inc.: 1-331.

[7] Gaunaris, Spiros P and karin Venetis. 2002. Trust in Industrial Service Relationship Behavioral Consequences, Antecedents, and The Moderating Effect of the Duration of the Relationship. Journal of Service Marketing 16. No7:636-655.

[8] Hair J.F., Anderson Rolp. Tatham E., Ronald L. and Black William C., 1998. Multivariate Data Analysis, Fift Edition, New York' Prentice Hall International Inc.

[9] Hardiman, Achmad. 2003. Rumah Sakit Indonesia Belum Siap Bersaing. http://www.kompas.com/kompascetakr/0412/22/humaniora1455383 html-4k. (akses 4/21/04)

[10] Hawkins, Del I, Roger J Best and Kenneth A Coney. 2004. Consumer Behavior, Building Marketing Strategy. New York: Mc Graw Hill Companies, Inc.:625-651.

[11] Hutton, James D and Lynne Richardson. 1995. Healthscapes: The Role of Facility and Physical Environment on Consumer Attitudes, Satisfaction, Quality assessments, and Behaviors. Health Care Management Review 20: 48-60.

[12] Jefkins, Frank.1992. Public Relation. Terjemahan Haris Munandar. Jakarta: Erlangga: 9-33.

[13] Kotler, Philip. 2003. Marketing Management. Engelwood Cliffs: Prentice Hall International Inc. A Division of Simoon and Scuster: 64-451.

[14] Lamb, Charles W, Jr, Joseph F.Hair, Jr and Carl McDaniel. 2002. Marketing. United States of America: South Western College Publishing: 167- 483 .

[15] Lim, Cheng Puay and Nelson K.H.Tang. 2000. A Study of Patients Expectation and Satisfaction in Singapore Hospital International. Journal of Health Care Quality Assurance 13 No.7: 290-299.

[16] Lovelock, Christoper and Lauren Wright. 2002. Principles of Service Marketing and Management. USA: Prentice Hall Internasional. Inc.: 50-325.

[17] Muninjaya, Gde A.A. 2004. Manajemen Kesehatan. Jakarta: Penerbit Buku Kedokteran EGC: 220-234.

[18] Morgan, Robert and Shelby Hunt 1994. The Commitment-Trust Theory of Relationship Marketing. Journal of Marketing 58: 20-38.

[19] Nguyen, Nha and Gaston Leblanc. 2002. Contact Personnel, Physical Environment and Perceived Corporate Image of Intangible Services by New Clients. International Journal of Service Industry Management 13: 242-262.

[20] Sabarguna, Boy. 2004. Pemasaran Rumah Sakit. Yogyakarta: Konsorsium RSI:1-21.

[21] Setyorini, Indah Lestari. 2009. Pengaruh Physical Support dan Contact Personnel terhadap Citra Rumah Sakit dan Kepercayaan Pasien pada Rumah Sakit Umum Situbondo, (Tesis), Pascasarjana Universitas Jember.

[22] Singarimbun dan Soffian Effendi.1995. Metode Penelitian Survai, LP3ES, Jakarta: 166-168.

[23] Snook, I Donald. 1992. Hospitals, What They Are and How They Work. Gaithersburg, Maryland: An Aspen Publishers, Inc.: $65-89$.

[24] Stavins and Fache. 2004. Developing Employee Participation in the Patient Satisfaction Process. Journal of Healthcare Management 49: 135-139.

[25] Sugiono, 2000, Statistik Untuk Penelitian, Bandung, Alphabeta.

[26] Sulastomo. 2000. Manajemen Kesehatan. Jakarta: Gramedia: 117-175.

[27] Surjaningrat, Suwardjono. 1997. Kumpulan Peraturan tentang Rumah Sakit. Jakarta: PT. Mitra Info: 1-285.

[28] Zeithaml, Valarie A and Mary Jo Bitner. 2000. Service Marketing. Singapore: Mc Graw-Hill Companies Inc.: 3-287. 